\title{
ROUTES TO FORMING AN AFFILIATIVE POSTMEMORY ABOUT DIFFICULT PAGES IN HISTORY (BASED ON THE EXAMPLE OF THE ERA OF POLITICAL REPRESSION)
}

\author{
Yulia V. Zevako \\ Laboratory of Human Inter-studies \\ Institute of History and Archaeology \\ Ural Branch of the Russian Academy of Sciences, Russia \\ milirita@rambler.ru
}

\begin{abstract}
This article discusses the mechanism behind the formation in adolescents (representatives of the 4th generation) of an affiliative postmemory about one of the most controversial and complex subjects in Russian history - the era of political repression from the 1930s to the1950s. The first part of the article is devoted to questions of methodology and necessity, and to the possibilities of using an authentic space and an authentic artifact as mediators between past and present in memory practices. The basic ideas are the concepts of "postmemory" by Marianne Hirsch, "grief" by Alexander Etkind, and "affective management of history" by Sergey Oushakin. Additionally, there are the ideas of Varvara Sklez, Veronica Dorman, Olga Strelova, and Alexander Kotlomanov in relations to that very authentic space and/or artifact which helps to provoke and form the memory of complex pages of history, not from within, but from without, enabling the creation of a kind of "sensory laboratory" for the period. Thanks to this "feeling", dry information is experienced and appropriated by a person through the strong emotions provoked, and the level of individual affiliative memory of the era of political repression is built up. The second part of the article describes two experiments which allowed me to analyse the effects of an authentic space (an immersive drama performance) and an authentic artifact (an archived investigation casefile) on adolescents.
\end{abstract}

Keywords: affiliative postmemory, archived investigation casefile, era of political repression, executioner, immersive drama performance, memory practice, postmemory, students, the Great Terror, victim

The twentieth century was full of dramatic events for Russia and European countries, associated with the activities of totalitarian regimes. However, although in Europe the Holocaust trauma was worked through as a result of the activities of various social, political, and cultural institutions, and a certain 
public consensus was reached, for the whole of Eastern Europe, including Russia, the pages of the history of the repressive policies of the Stalinist regime, and in particular the Great Terror, are still not fully understood, having instead become the subject of "memory wars", and an instrument of "conflict policy". This becomes especially important in a situation where representatives of the fourth and later generations turn their attention to the painful events of the past. The question arises for cultural actors: how can we formulate a memory of a difficult past in such a way that it is perceived deeply and emotionally, and becomes personalized for new generations of adolescents?

\section{THE METHODOLOGICAL BASIS FOR THE STUDY}

The author's own experience with senior secondary school classes has shown that touching on so-called difficult subjects of twentieth-century national history leaves teenagers with more questions, bewilderment, and dissatisfaction than it gives answers. They have neither the capacity, time, research tools, nor the authentic historical materials required to question and to adequately criticize conventional beliefs and stereotypes. Meaningful, deep, reflexive thinking, developing one's own point of view, and a personal, reasoned attitude towards the topic requires not a one-off study of the era, but a systematic and wide-ranging contact with it.

The development of such a system, and its methodological justification, were based on a range of theses. The first is the concept of postmemory developed by Marianne Hirsch: postmemory is "memory after memory", the memory of people about an event in which they were not directly involved, and which they did not witness. The researcher identifies three levels of postmemory: familial, affiliative, and associative (Hirsch 2016).

If I briefly summarize those provisions of Hirsch's concept of postmemory which are important for my work, I can say the following: the formation of postmemory about traumatic events, when it goes beyond the initial postmemory and begins to involve other people in the process, usually occurs / should occur at a deep emotional level, due to imagination and projection. It prompts the recipient to go through the pain of others experienced by their forbears, a pain which is distant from them in time and space, to appropriate their emotions and experiences, and to achieve a certain empathy and solidarity with them. After three or more generations, this becomes possible only through the development of special "mechanisms for the transfer of traumatic knowledge and materialized experience". Such mechanisms include the "reincarnation of 
memory through other institutions", when they "give people the opportunity to relive these stories, [give] the possibility of personal identification with someone else's memory". One of these mechanisms is immersive practices (in our case, immersive memory practices) - a theatrical technique based on the involvement of the viewer, their "immersion... through the impact on all the senses", that is to say, through sensations (Zevako 2019: 395-396).

When putting forward his own concept of grief instead of trauma, Alexander Etkind emphasizes that Hirsch's concept of postmemory is easier to understand precisely in terms of grief, because "trauma is a response to the state in which I have found myself, grief is a response to the state of the Other" (Etkind 2016: 27).

A number of domestic and foreign experts also note this feature of working with the memory of traumatic events, in particular with the memory of the era of political repression. For example, Veronica Dorman focuses on the fact that "the memory of Soviet repression does not arise from within or from nearby, but from outside and at a distance, and it must not be so much stored and protected, as provoked, organized and actually formed" (Dorman 2010: 331). Achieving imaginary, symbolic intimacy with victims enables a special kind of contact with history: both as a real contact, the direct, bodily contact of a person with objects of history or identified history, artifacts, etc., and as a symbolic contact, through imagination, co-attunement, empathy, and emotions. This effect is achieved through affect, which helps to produce what Sergey Oushakin calls "chronographic cross-linking" (Oushakin 2014), or what Varvara Sklez describes as the ability to "transcend temporal, spatial, geographical, and national boundaries, to journey through both material and virtual remnants (for example, a song or a phrase)" (Sklez 2016: 226).

That is to say, the physical touch of a historical artifact (even if in the event it turns out to be a certain space rather than a thing - for example, the burial site of the executed victims of political repression) is important not in and of itself, but rather as the creator of the conditions necessary for the symbolic touch, conditions in which the appearance of an affect that overcomes borders becomes possible. Chronographic stitching turns out to be the more effective the more saturated and multi-layered the place is, when there is something there to "stitch" - the real interacts with the symbolic through imagination and empathy, and vice versa.

Alexander Kotlomanov points out the special relationship between space and memory. In his article, he considers from an aesthetic and symbolic point of view the "Masks of Sorrow" memorial to the victims of political repression (Kotlomanov 2017), erected in the centre of Moscow in 2017. Analysing the 
description of the sculpture's design, he notes that it "recalls the tradition of creating memorial complexes, which was widespread in the USSR and Eastern Europe after the end of World War II... As a rule, these architectural and sculptural complexes [were] interconnected with the place where they were built, thereby perpetuating the space of a historical tragedy. ... The characteristic difference between the new memorial and many famous examples from the Soviet period is the former's location, which is unlikely to be associated with something specific, with something that could be considered a symbol of the 'spirit of tragedy"' (Kotlomanov 2017: 444).

Furthermore, Kotlomanov references an article by Grigory Revzin, devoted to the same story, emphasizing the special importance of the interaction of space and monument for the formation of a memory space: "A place has been chosen... The only thing that can be said definitively about this place is that it is not distinguished in any way, it is an empty lot that arose by chance during the planning process for Novokirovsky Avenue. This is a bad decision in itself. In order to be noticed, a monument must be placed in some symbolic place. Or rather, the more symbolic the site chosen for it, the more effectively it will work. Here, the location does as much as possible to weaken the potential significance of the monument" (Kotlomanov 2017: 444).

In her article "History classroom - still 'a field of battle for the past', as 'memory wars' rage on”, Olga Strelova considers among other subjects examples of memory museums (in which the spaces and buildings themselves are authentic places, potentially filled with history and memory), highlighting the House of Terror in Hungary, about which the authors quoted by her write: "The museum should not document history, but rather allow the visitor to feel and touch, so to speak, the substance of terror. The main task of the museum is not to present exhibits, but to provide a direct visual appeal to emotions" (Dr Mária Schmidt, Director of the House of Terror); "the House of Terror is not a traditional museum; it is organized on the model of postmodern museums in Great Britain and the United States. It might even be called a sensory laboratory" (Mark Pittaway) (Strelova 2012).

Sergey Oushakin notes that the "ordering effect is achieved not through the traditional building of a canonical narrative (in this case, the normative version of history), but through the emotional codification of events, things and/ or symbols of the past... Affective experience ... stimulates the schematization of the understanding of historical events using concepts that have a personal meaning". The emotional experience of the past serves as a mechanism for appropriating that past. Oushakin calls such practices of the activation of sensory reactions using historical material the affective management of history: here, memory and perception are, if not fused together, then at least undivided. With 
this attitude to history, the facts of the past are not so much taken into account and recorded as actively experienced, as phenomena which continue to retain their emotional impact (Oushakin 2014).

The scholar considers this concept more as a way to work with mass consciousness, with public space, with memory in public. However, within the same logic we can also distinguish a point-based, individual affective management of history, associated with individualized memory practices that focus on creating a less smooth and monotonous, more individualized landscape of memory/ representations/feelings relative to a specific chapter in history.

In fact, we see that the affective management of history is indeed aimed at working with the affiliative postmemory, as a result of which the information acquires a special depth through the truly lived feelings of the subject. In this process, an important role is played by the use of an authentic space/artifact, which enhances the affective effect, that is, the emotional connection and the assimilation of information.

This study is devoted to testing this thesis in practice. On the one side, the author of this article, together with colleagues from the Museum of the History of Yekaterinburg, developed a project titled "You Can't Keep Silent: Practices of Memory about the Era of Political Repression", ${ }^{1}$ the target audience of which is teenagers aged between 14 and 19 years old. First, participants were asked to go through the "touch" stage of this topic through various events, including an audio-guided bus tour called "The Route of Memory", ${ }^{2}$ an immersive drama performance at the "Case of F. Zagursky No. 39496" memorial to victims of political repression on the $12 \mathrm{th} \mathrm{km},{ }^{3}$ an excursion to the GAAOSO - the State Archive of Administrative Bodies of the Sverdlovsk Region, and individual work with archived investigation casefiles. The task of the second stage is to translate one's emotions, experiences, ideas, and thoughts into a unique creative product according to one's abilities and desires in one or more laboratories (research, journalism, media, theatre or art) under the guidance of specialists from the chosen field.

On the other side, a research tool was developed that enabled us to track the internal mechanics of the formation of the affiliative postmemory in representatives of the 4th generation (when contact with a marked piece of history in the form of an authentic space or artifact helps the information to acquire a special depth through actually lived feelings).

This article will analyse the effects of two practices of touching the era of political repression - participation in an immersive drama performance, and individual work with archived investigation files.

Accordingly, in the first case, the focus of the study was the emotion-spacememory interaction, in the second, the emotion-artifact-memory interaction. 
The task was to trace the possibilities and mechanisms of forming an affiliative postmemory (a postmemory based on emotional involvement) through the specially organized interaction of recipients with an authentic space and/or artifact.

Particular attention was paid to measuring and recording changes in the intensity of emotions in each case. This idea was prompted by the reasoning of one of the students. When I asked: "What did you get from the more in-depth work with the topic of repression at various extracurricular events?", she replied: "I used to feel sorry for them [the people affected], and now I feel very sorry." I realised that the change in the depth of (co)feeling is not obvious and does not lie on the surface, but is rather a serious and important personal result, and an indicator of the effectiveness of forming an affiliative postmemory.

In spite of the fact that in the last few decades there has been an emotional pivot in the social sciences and the humanities, representatives of different subject areas still do not have a single idea of what emotions are. Moreover, there is no clear line drawn between feelings and emotions, which are often used by researchers as terminological synonyms (Simonova 2016: 12-27).

This article is based on the position of Vladimir Ilyin, who says that "emotions are an external, observable manifestation of feelings that often have a hidden character. Feelings are an essence that appears in the form of emotions. It is actually through emotions that feelings become visible, turning from a purely personal experience into a social fact... Emotions indicate the presence of corresponding feelings" (Ilyin 2016: 34).

In addition, a note should be made of the following feature of emotions: they "act as highly reflexive phenomena... Reflexivity is expressed in reflexive identity, reflexive life history, and observation of feelings provides the individual with a sense of validity/authenticity. Emotions become the 'drivers' of moral choice aiming to confirm one's identity". Thus, "emotions are presented as a kind of 'key' to the authentic human experience" (Simonova 2018: 372).

The main tools selected to investigate this authentic experience were Carroll Ellis Izard's Differential Emotions Scale (Kunitsyna 2011), and an open-ended question and interview method.

The theoretical basis of the DES (Differential Emotions Scale) is the Izard's model. According to this theory, there are ten fundamental emotions that determine the component composition of the most diverse manifestations in a person's emotional life: interest, joy, surprise, sadness, anger, disgust, contempt, fear, shame, and guilt. The DES method enables the creation of a cross-sectional snapshot of the whole palette of current emotional experiences, and analysis of the affective components regulating current activity, components which reflect the features of the projection of motivational attitudes in the current situation (Kunitsyna 2011). 
The respondent is asked to evaluate the acuteness of each emotional experience on a five-point scale - from complete absence (one point) to maximum intensity (five points). ${ }^{4}$ A convenient format for qualitative analysis of the results is the construction of an "emotion profile" for all ten basic indicators, the peaks of which correspond to the most vividly coloured types of affective experiences. For a more general description of the type of emotional experiences that dominate in a particular situation, we can analyse the aggregated assessment blocks: A - actualization of positive emotions (interest, joy, surprise); B - actualization of acute manifestations of negative emotions (anger, wrath, disgust, contempt); $\mathrm{C}$ - the presence/formation of a relatively stable background of anxiety-depressive experiences (fear, shame, guilt) (Kunitsyna 2011).

The participants filled in a questionnaire at the project's outset, after the immersive drama performance, and after the casework. This allowed us to identify and track changes in the intensity of certain emotions. In addition, data on the permanent members (the teenagers who filled in the entry form and participated in both the activities) enabled us to compare the emotional state of the aggregate respondents in general (the teenagers who had only filled in the entry form).

In the survey materials after the immersive drama performance, the participants were asked to answer a number of questions that helped to explain/clarify the stories emotionally most vivid for them; at the end of the performance, they were interviewed in the format of a free statement in response to the question "What caught me / touched / interested me the most?"

The survey material after working with the archived investigation file also included a number of additional questions, and an explanation column after Izard's Differential Emotions Scale, in which respondents were asked to unpack the emotions most important for them.

At various stages of the project, 57 people took part in at least one event (the filling in of the entrance questionnaire), 28 people took part in the immersive drama performance, and 23 people took part in work on the archived investigation casefile. Of these, 16 people participated in both events, which involved filling in Izard's Differential Emotions Scale, and 13 filled in the survey material.

The article is based on the content analysis of this material. The analysis of the emotional impact of the immersive drama performance and work on the archived investigation casefile were carried out as a comparison of indicators from the entrance questionnaire and the questionnaire after each teenager took part in the event. The quotes presented in the text below remain anonymous. 


\section{EMOTIONS-SPACE-MEMORY}

In accordance with the idea of director Irina Lyadova, the immersive drama performance was divided into several stages, which made the most of the space of the memorial and the small exhibition-utility room located on its territory. The performance began in this room, and the final reflexive conversation also took place here. The first stage included being photographed face-on and in profile, handing over personal belongings, filling in the questionnaire of the person arrested, and counting aloud the number of people who had been shot (at the memorial, 19,410 people have been identified by the archives to date).

Later on, the participants noted that this stage "strongly influenced the psyche": the requirement to follow instructions aroused both "fear and interest, due to the understanding [that this was] an allusion to the situation of being arrested, [and] the charges; "I already had goose bumps... it was somehow uncomfortable", but "when they took away all our things and told us to write down our details" - this led to an unexpected (amazing and frightening) discovery: "you feel just how simple it is to take a human life"; "very intense... when you are asked for all your information - the feeling that something is wrong, you start to feel awkward and... afraid of something... afraid maybe even for your relatives, that they could find them or something..."; "I thought, if I make some mistake, they will immediately take me away to be shot, I don't know".

A special effect was produced by counting aloud - the numbers also seemed to be identified in the sound and became a medium between past and present: "When you just see this number - 19,410 - that's one thing, as it were. But when you start counting, then... well, this is really a lot"; "I may have realized that this is a real number, but it really gets to you when you have already got to the third hundred and you are still counting... that is, you have not even reached a thousand, and there are nineteen of them".

The next stage - interrogation - is the reading of the Interrogation Protocol of Filipp Zagursky by roles (investigator/accused), and a short comment and explanation by the actor. Then - a walk through the memorial stones to the site of the first excavations, which uncovered the remains of 31 people, including those of the main character of the play - Zagursky himself. After that - a long, winding forest path to the next site. All three stages, having as they did a more informational rather than emotional and dramatic orientation, created the factual basis for a deeper and more meaningful experience of the next stages "the apple grove", "the pit", and "the stone".

The apple grove stage was divided into two parts: first, the teenagers came in pairs to a tree, to the branches of which kulechki peredachek (small bags or 
packages) were tied. Some packages had names written on them, others were nameless. The actor talked about how difficult it was to get food, that kulechki were accepted only at the time and place allotted for this purpose, and that it was no accident that the apple grove appeared in this forest: young trees were planted at the burial sites of those who had been executed, as apple trees grow quickly. Next, the participants were asked to take one of the packages (and allowed to see what was inside) and to take it to the person to whom it was addressed, if a name was marked on it, or to leave it with any person if no name was written. After that, they moved to another part of the grove, where photographs of people who were shot and later rehabilitated had been placed on the ground and on the trees, with brief information about them. Some time was given for walking around the apple grove, reading the information, placing the kulechek, and just spending some time in this place.

The analysis of the survey materials and the conversations after the performance enables us to reconstruct the thoughts, emotions, and motivations of the teenagers, to understand the internal mechanics of affiliation with the events of the era of political repression. The question was posed in this way: the name of the stage - what did you do? Why?

The desire to find out what was passed to the prisoners, their interest and curiosity prompted the teenagers to look inside the packages first: "The kulechek hung on a tree by a thread; I tore it down, opened it, and there were two small potatoes and a piece of candy in it"; "I chose a package, and inside it were boiled potatoes, cigarettes, and candy"; "I carefully examined the contents of the parcel". Then, on the strength of their own ideas on how this could be, intuitively, the teenagers played the role of the imaginary postman, of the medium physically and symbolically connecting the past and the present, passing/returning in the present day what had not been received, or not received in full, in the past: "I delivered the package"; "I ripped it open and took it to the photo of the dead person"; "I took one package and handed it to the repressed man with the terrible fate"; "I took a bag and placed it by the photo of a woman"; "I looked to see what was in the bag, I left it beside a photo"; "I took a bag, opened it, and read the biography"; "I took down a bag, and put it beside one of the photos".

Curiously, for many of the students, the anonymous recipients ("I placed a bag beside one of the repressed"; "I put a package next to the photo of a person who was shot in 1937 and only acquitted in 1956"; "I put [a bag] beside an old man, because I felt sorry for him") found quite specific names ("I put it next to Zorin"; "I left it by V.M. Tarik"; "I put a package beside two photos of Feoktistov at one tree"; "I left a parcel to N.F. Zbykovskaya"). The chronographic cross-linking was that, at the moment of sending the parcel, the line between 
the past / the dead and the present / the living was blurred; at that moment, the recipients were perceived by the teenagers as living people ("living dead"): "I wanted to be nice to the deceased and gave the person [plaque] a sign of it".

The demonstration of care, and the returning of what was never received, was expressed by the teenagers in their involuntary desire to be nice ("I straightened his portrait"; "I looked into his eyes"), to feel pity ("I felt very sorry for the man who didn't receive a package from home"; "I became very sorry for the relatives of the repressed"; "I felt sorrow for the people who brought the parcels"; "After all, the people who cared about those who had died had to be sure that their efforts to put together the parcel were not in vain"), and to understand ("to understand what people experienced, what feelings they had when they received the parcels") both those for whom the parcels were intended, and those who sent them.

The lived emotional experience of injustice, which engendered "an unpleasant feeling of persecution", "shock at how people were treated by state structures", "grief for the dead and hatred for those who did it", resentment ("it was very insulting for those people who did not receive their parcels, who could not send parcels to their nearest and dearest, could not help in any way, write letters"), anger ("Most of all I was hurt by the packages. Because... when a person's family is taken away, it is unclear what will happen to them, their future fate... they are accused, you have to give some false testimony... and then it turns out that... You look for them all over the country... and it turns out that you went all this way in vain, the parcels all subside away to nothing") also prompted an internal need to see justice restored ("It's time to return the person's property"; "I wanted the person to get what was sent to them").

The authenticity of the place (the knowledge that these apples were grown not for beauty, but to hide a secret - namely, the people who had been shot), contributing to the imagination of those who were long dead (shot) being alive ("When you're in the midst of these apples, you already know that beneath the earth there is now a bone"; "the trees grow on bones"), reinforced the authenticity of the feelings of concern towards them: "I wanted to feel like I helped someone", if indeed it was still possible to do something to help.

Then the pupils went individually or in pairs to a pit that was 2.5-3 metres deep. The actor ordered each participant to go down into this grave-pit, and after one to two minutes gave the command to climb back out.

The provocation of the affiliation mechanisms - projection, imagination, empathy - occurred even before the descent into the pit: "When we were walking along this long road [to the pit], I could not get out of my head the fact that just before this we had been told that there were large burials in the places 
where the land had subsided. And I noticed out of the corner of my eye that here, right here there might be something"; "We were told that the land had subsided - all the same, the logic works in my head... I looked around, and the area was all like this...". This contributed to a co-attunement with the space, the emergence of curiosity ("I was very interested to go down there", "because I'd never gone down into such a hole, so deep. I had climbed up high, but I had never gone down. It was interesting to see from below..."; "the feeling - the incomprehension as to what will happen next") and the desire to test oneself ("I wanted to feel the isolation of the space and seek new sensations"; "I wanted to plunge deeper into this atmosphere"), as a result of which none of the students refused to descend into the pit (even though one of them resisted (morally), and another was ashamed, since the grave was a "holy place").

Each participant spent one to two minutes in the pit: sitting, standing, examining, watching, "waiting for someone to call me back up" to "get out as soon as possible". Many noted that in the pit time somehow flowed more slowly: "I was in the pit for 5 minutes" [in fact, no one was in the pit for more than two minutes]; "I was there only for two minutes, but it felt like I spent about ten years there".

The authenticity of the memorial space, the knowledge of the number of people shot and buried in this place, helped to switch on the imagination, and to associate the pit that the students had themselves descended into with the pits that were all around ("thousands of people lie underground and this is one of those very pits"), thereby projecting their own experienced emotions onto the victims of the repressions, and vice-versa ("I tried to look up with the eyes of a dead man, to hear every rustle"), which allowed them to feel more deeply the atmosphere of that time, and to understand through their own selves the possible state of mind of those people.

The notional "grave" in the place of mass graves for victims of political repression enabled the provoking of an instant co-attunement with the past, a "stitching together" of the past and the present: experiencing genuine fear from scary, and a little scary to terrible and creepy ("it seemed that I was about to see a bone inside the pit"; "maybe there is a pile of corpses"); many participants projected this fear onto the victims of repression of the past, associating themselves with them in the present. So, they noted that they felt "hopelessness, fear, as if it was me they want to punish"; "it seemed to me that I'm about to be buried or shot"; "it felt like it was the last minutes of my life"; "an incredibly strong feeling that you're alone and... it was just frightening"; "when there is four metres of earth above you and you are standing here in this little pit and you feel buried alive"; "This feeling of doom arose... and... 
I even had this fleeting thought... I thought he [the actor] was about to pull out a machine gun. A fleeting and, of course, a stupid thought, irrational... but nevertheless... that's how it seemed".

The palette of emotions ranged from complete emptiness and numbness ("I felt constrained"; "I did not want to move, I did not want to think about something"), depression, hopelessness, humiliation ("You are in there, and someone is looking at you from above - from the side of those who, let's say, do the burying... Like that... As if there is someone strong, and you are weak"), extreme discomfort, awkwardness, and heaviness to the point of almost physical pain.

The metaphor of life and death was especially discernible in the pit space: "When you are in the pit you just look up and realize that there are living people up there... And in the pit itself, even the vegetation itself is still green, as if it is still alive, but it... it is already frozen, everything is frozen..."; "In that pit, when looking up, you [see] life outside the place of your "prison".

The wrongness of what is happening is here and now with the teenagers themselves: the living should not be standing in graves to experience the unnatural state of being buried alive, to disturb the dead ("The understanding that... maybe with my presence I am disturbing... I don't know... the history of this place..."; "Initially I jumped into the grave, without even thinking - whose is this grave, and what is actually there. And now it weighs heavy on my soul because of that... there are people still lying dead here, [in this pit there were no burials], and they should be respected"; "You don't know whether people were buried here or not, it's very hard, it's really very hard, it's just impossible") on an emotional, symbolic, and physical level. They thought about the injustice of what had happened back then: "In the pit when I went down, I saw the numbers - the number of people who died - and I felt ill at ease that it was such a large number, and it was somehow too cruel... And then by chance it turns out that they are innocent, they are rehabilitated"; "I read how many people were killed there, and I just felt so awful: oh, so many people - and they are all here. This is terrible"; "These people did not die their own death, they were unjustly condemned and killed... and you can just jump in, and get out again"; "Just at that moment of being in the pit... I was struck by the understanding of the ruthlessness of this giant mechanism - the repressions, in which people died as if they were on a conveyor belt - mostly innocent people".

The natural continuation of the awareness of injustice was the desire to restore justice - for example, in the form of a conventional symbolic gesture ("I put my hand on the stone on which 19,410 was written, to honour their memory") or an attempt to "overcome temporal, spatial... borders" to convey to those who had been executed what they had been deprived of back then - rest and solace ("I tried to 'find peace"). 
After the pit, the participants went one by one or in pairs to the next stage to an actor standing on a hill in front of a ravine. Next to the actor were some stones, on one of which was written the number of the case of Zagursky. In a stern voice, the actor ordered them to throw a stone into the ravine and handed them a tin of stewed meat "for a job well done".

This movement from stage to stage, together with an unknown plot twist to the climax of the performance, seemed to gradually accustom the students to a loss of subjectivity - of their ability to intelligently and critically approach the actions proposed, and to independently make decisions. In response to the question "What did you do?", the students answered: "I climbed the hill and threw a stone"; "I threw [the stone] and then picked it up and put it back"; "I threw the stone and returned it"; "I threw it"; "I threw it down"; "I dropped it". When filling in the questionnaires after the performance, some students added: "I reluctantly threw it, and I got the stewed meat"; "I threw it off, not knowing there was a choice"; "I threw it off, but with difficulty"; "I threw the stone off, but it didn't make it"; "I threw off the neighbouring stone", as if trying to justify themselves and their actions.

They understood only later what horrible thing they did at this stage ("I felt that I had done something wrong"), which subsequently caused an internal need to search for exculpatory formulae that would allow them to remove the emotional tension and moral responsibility: "I was told to"; "I did what I was told to do"; "without thinking, I threw the stone"; "I did not understand why it had to be done"; "I did not think that there was a choice"; "I threw it down, well, without thinking... they said it - and I did it"; "at the time I didn't understand the point... either I was not thinking, or something else..."; "I did not immediately understand the subtext with the stone"; "I actually wanted to find a small stone, not this one... Maybe I also did not understand at once the message, the metaphor, the symbolism ... of throwing that stone"; "I did not realize at once what it was. I realized only after ten to fifteen seconds once I had left the place - then I realized what I had done..."; "You throw it - you perceive it just as a task, and then, when you are already leaving the place, then you understand that you have killed someone and been given a can of stewed meat in return."

The unexpected metamorphosis in the roles performed by the participants made a strong impression: first, a vast majority of pupils passed through an emotional co-attunement with the memorial space and the victims of the political repressions (through genuine feelings of fear, despair, loneliness, injustice, compassion, a desire to help and to comfort, and to see justice restored). Then suddenly they are the "butchers" who killed this victim, they have created the condemned and experienced injustice with their own hands. The understanding 
of this does not come immediately - for some after ten to fifteen seconds, for others a little later.

The inner turmoil that most of the participants experienced at this point was difficult to express: "then you understand it and... sort of... YES!"; "the soul weighs heavy from this understanding... I'm really..."; "the weight, it was very hard..."; "there was a load"; "morally hard"; "something sinks somewhere inside"; "I felt disgusted".

The role of the soldier who carried out the sentence and the ill-fated tin of stewed meat as "a kind of payment for the murder" provoked and formed, in addition to regret, horror and sadness, and the two key feelings - shame and guilt: "I wanted to throw this tin of stewed meat somewhere far away and go home! Honestly... the biggest feeling I feel now is shame and guilt"; "All the way back I walked and apologized in my head, because I felt bad... I wanted to apologize to everyone [those who had been shot] ..."; "Being given the stewed meat really upset me"; "I'm very sorry; I would do anything to fix my mistake". It is probable that this metamorphosis became very painful for the participants because the line between the victim and the criminal, which had previously seemed obvious, became ill-defined.

Afterwards, the teenagers returned from the forest near the memorial to the memorial space itself. There they were invited to honour the memory of the repressed in a way that was comfortable and appropriate for them (bread, candles, matches, etc., were laid out on a blanket), as well as to walk around the memorial, to find the name of $\mathrm{F}$. Zagursky, of their namesakes, and simply to spend some time in this place.

The teenagers were then invited back into the building one by one, where they were given back their belongings and their "case"-files, and where they filled in a questionnaire sharing their thoughts and emotions.

The unpleasant, uncomfortable experience of fear (I am the victim), and of shame and guilt ( $\mathrm{I}$ am the executioner), emphasizing the complexity and inconsistency of the era of political repression itself, encouraged the teenagers to ask questions about the nature and essence of the events that took place from the 1930s to the $1950 \mathrm{~s}$, as well as about the society and state of that time: "I had this question in my head: the soldiers who did this, what did they feel? Did they feel, well... compassion for these people, or did they stop feeling it when they killed more than one person every day... what did they feel then?"; "Is this the only place in Russia where so many are buried... or is the whole of Russia one big burial ground?"; "What happened in the country that people were treated this way? Why couldn't we deal with them in a different, more humane, more human way? ...It's so strange, it's not clear why, why exactly did it happen?"; "I can't get over the realization that this was.... that this could at 
all... in principle... that this could happen in our country"; "I do not understand why all this happened".

The anxiety, incomprehension, and surprise caused by the imaginary touching of the past changed their direction of travel after the performance: the spatial and temporal boundaries were now overcome in the opposite direction. If there still remained an interest in the past ("very strong interest, to learn as much as possible"; "I want to know what was in our country before us"; "because we were not around then, and we do not know how people lived then, what they felt, what they experienced"; "I am very interested in learning about the history of the country - how everything happened, how people lived then"), along with sympathy and a duty of remembrance ("to remember and honour the memory of people who are dear to us, just people who were convicted back then without any guilt, without any reason..."; "to find maybe after this performance my own relatives who were repressed"; "at least to remember those who... and they are still finding people who were repressed in these pits to this day"), then the fear and a sense of injustice which they felt during the performance through their own experiences ("What affected me most was that the cases were fabricated... that these people were just like all of us... and if we had been there then, the same thing could have happened to us... it could have been us") came to be projected onto the present: "It was probably hardest at the end. When you realize the scale - and once again... you know that now too, because we are now also at such a level that a little more, just a little bit more, and..."; "At the moment we are moving towards a pushback, you might say... Now it is coming little by little: the children have a voice, the government does not like that, and gradually we are on the slippery slope, the people need to be silenced somehow... and it's quite scary - at least for the future, for the position of..."; "You understand in principle all the cruelty of human [nature]..., and it's scary that similar things are going on somewhere now, and may appear again sometime in the future"; "What if this all happens again"; "It's scary that all this will happen again"; "I don't even know how to relate to it - whether to prepare for it, or to resist it... But it's not clear how...".

The prospect of a future in which there would be no choice, no possibility to prove their case and defend their good name, where they would have to sign false statements and dissemble in order to survive, or die for nothing, was terrible ("When we were writing [filling in the questionnaires], there were not just awkward questions, but questions that I didn't want to answer at all. And those people who came here - they arrived already doomed... they had no choice. Many people did not want to admit their guilt, they wanted everything to be fair, but circumstances forced them to... to lie... not for their own benefit... but just because you they had to..."; "I was shocked that people had 
to plead guilty for something they'd never done..."; "It's unpleasant, offensive, and sad... and somehow, even anger creeps in, when I think that people were unfairly convicted, that they were killed"; "How many good people were... for the smallest offences... killed"), as was the idea of hiding or erasing the faces of their family in photographs, as if rejecting them ("When we were told that on some of the photos faces were hidden, because their relatives despised these people, that they could betray their country and all that stuff. ...if I were in the place of the relatives, I would, on the contrary, reveal the face and try to prove the innocence of this person. Because... well, it's like one of your own"; "You've known him, for ten years, you know all his faults... But in one moment you just go and abandon this person and say that you do not know him, that you cannot know him... how is such a thing possible?"), or being forgotten ("When people were repressed, they were expelled from the lives of the people, the country, the town where they had lived, they were forgotten... and people did their best not to remember them too often...”), or becoming a victim or an executioner.

The analysis above enables me to suggest that the participants in the performance, through their own "truly lived feelings" were able to achieve a certain empathy and solidarity with those who had taken part in those events - on both sides of the case: the unambiguous images of the executioner and the victim acquired a more complex structure.

The executioner is at once the system (the dictatorial regime, the leader, the people admitted to power), the state, and the simple person who does the job without thinking, because they were told to.

The victim is not only the innocent people convicted of falsified cases, sent to prisoner camps or shot, but also their relatives ("I felt very hurt on behalf of those people who did not receive their parcels, who could not send parcels to their relatives, could not help in any way, write letters"; "You need to study and to feel what the people who were subjected to these repressions felt, and what their relatives felt").

Thus, both the executioners and the victims are, first and foremost, people just like us. The formation of an affiliative postmemory makes it clear that any one of us can be one of them. This becomes an unpleasant and unexpected discovery. The interest and desire to understand what it was and why it happened is related, in large part, to the fear of ending up, voluntarily or otherwise, in a role that causes strong resentment, a sense of injustice and internal resistance in the present.

In this sense, the restoration and preservation of memory about the events and people of the era of political repression, about the past, becomes a kind of moral beacon for the present, a reflexive work, the main task of which is not 
to be silent, but to speak out ("It seems to me that we are just now studying the times of repression. We are bringing these people back, remembering and bringing these people back into the life of our country... this is the right thing to do"; "We simply need to not be silent, and to talk about it, to try to somehow find out about our relatives, that yes, this happened... and not to hide or be ashamed of the fact that, yes, your relatives took part in it, and they were convicted; accept that it was so, remember it and talk about it...."; "If people feel panic, then they should show that they feel panic... the authorities will see that, and take some measures to restore some calm... that's what I think...”), not to condemn, but to try to understand ("To condemn the executioners who were there back then - in fact, what is the point now. Every time has its own executioners. We just need to know that this happened, and not allow the same to happen in our time"), not just to know ("it was"), but to feel ("how it was") ("...this is actually important in order to prevent the whitewashing of the dictatorial regime and the people who stood behind it...”).

Emotions, according to the Izard's Differential Emotions Scale, were distributed as follows according to their degree of intensity: interest (84.8\%), surprise $(64.8 \%)$, sadness $(60.8 \%)$. Then there was a differentiation between the girls and the boys: with a fairly high degree of intensity; the girls displayed emotions of shame (47.7\%), guilt (44.4\%), and fear (35.5\%), the boys - emotions of disgust (37.1\%) and fear (28.6\%), which complements the qualitative analysis of the survey material presented.

It was curious that, when filling in the Izard's scale immediately after the completion of all the stages, the participants identified interest as the dominant emotion, which turns out to be quite multifaceted. It is both the unusual format ("I did not expect such a format - it is rather unusual"; "When we got here, I thought it would be just an ordinary play about the repressions, that someone will play some scenes... and then when... there is such an atmosphere: so cold, cruel, and you plunge right down to your bones into this atmosphere of repression. It's so spellbinding, it so touches the soul") and the unpredictability of the plot, the content of the further stages, which made the performance similar to a kind of quest, and the new information that was also given substance in the form of sound (the counting up of those who had been shot), the ground caving in under feet (the story of the burials), the reward for killing (the cans of stewed meat); it is the intense feelings and emotions experienced at particular phases or throughout the entire immersive performance. And the theme itself, shrouded in a halo of mystery, isolation, and incomprehensibility, which is difficult, but you want to understand it. 
Thus, the actualization of positive emotions (interest, surprise) associated with the expectation of something unusual, unknown, and interesting, remaining at the same high levels after the event, was supplemented for all participants by the formation of a relatively stable background of anxiety-depressive experiences. Moreover, the boys were more likely to have acute manifestations of negative emotions than the girls.

The plot twists used in the play, coupled with certain dramatically played out memory practices, allowed the director and actors to create an atmosphere in which the participants were able to experience emotions and conditions that were perhaps close to those experienced by all the participants in the events of the Great Terror of 1937-1938. Each participant was able, to a certain extent, to recreate the atmosphere of that time for themselves and, through imagination and projection, to connect emotionally with the past. This co-attunement, carried out through substantiated history, where the main artifact itself was the authentic space of the memorial to the victims of political repression, helped to deliver the "chronographic stitching" and to overcome spatial and temporal boundaries.

The three central stages of the performance allowed each participant to provoke a special kind of experience about the past, which became part of their own memory (postmemory) about the era of political repression. The projection of their own experiences onto the past enabled the teenagers to identify themselves for a time with the people who had participated in those events, and at the same time to ascribe themselves to them, and to assign to themselves the feelings of those who had long been buried there. It enabled the students to achieve a certain solidarity with them - to feel and understand the fear of that era, to sympathize, to feel sorry for them, to try to participate in their fate and symbolically restore justice.

The performance turned out to be a kind of game played out in the space of the memorial, the authenticity of which contributed to the fact that the teenagers experienced strong emotions, and associated them with a specific place, period, and people.

\section{EMOTIONS-ARTIFACT-MEMORY}

The document-related work was divided into two parts (after each of which the participants filled in a short questionnaire): 1) a general introductory tour of the GAAOSO archive in Yekaterinburg, an overview and familiarization with the archive's equipment, the document collections, etc., related to the topic of 
political repression (26 participants); 2) focused/individual study work in the archive's reading room and familiarization (reading) with the archived investigation casefile ( 28 people, of whom 23 filled in the questionnaire). Several people went on to the research stage and more detailed work with the casefile and its further elaboration.

Of particular interest here was the second part - the work with an authentic archived investigation casefile from the 1930s. I presumed that the familiarization with the documents of the investigation file (substantiated history), which contains the history of the fate of individuals, may contribute to the formation of an affiliative postmemory about the era of political repression, through the emergence of empathy and sympathy for a specific person, and by provoking strong emotions in the process of comprehending the content of the documents (the detainees' arrest forms, interrogation reports, sentencing, denunciations, complaints, letters, etc.), revealing the innocence of the convicted prisoners and the unfairness of the charges.

Processing the results of the questionnaires and interviews with some of the students enabled me to make the following observations and conclusions.

The main emotions in terms of intensity when working with the archive file in person were interest (83.8\%), surprise (58.8\%), and sadness (38.8\%). The young people who came to the project later got acquainted with the archival cases from photocopies, but they had a greater range of emotions in terms of intensity: interest $(76 \%)$, sadness $(68 \%)$, and surprise $(56 \%)$, and were supplemented with the emotions of shame (60\%), guilt (48\%), disgust (44\%), and anger $(44 \%)$. We can assume that this is because the second set of teenagers came with more interest in the topic, or because they had the opportunity to read the documents more carefully, to read small extracts, to discuss the details with someone else, etc.

Nevertheless, it is obvious that, in and of itself, working with an authentic document - regardless of how it is presented, in the form of an original or a photocopy - caused a strong emotional response from the respondents. The dominant emotions (as in all the project's activities) were interest and surprise. It is likely that, depending on the individual characteristics of the teenagers, their internal expectations, their individual susceptibility and interest in certain aspects of this topic, sadness, shame, guilt, disgust, and anger manifest themselves with different degrees of intensity.

The direction of these emotions, their specific vector and content help us to understand the comments of the respondents. What constitutes interest for a teenager? First of all, the archive document itself (the familiarization with the archived investigation casefile), which was interpreted by the students not just 
as a new, or novel, but a really unique experience: it was interesting "to read old documents and decipher the strange handwriting of the investigators"; "to examine every detail, to dissect every written word, gradually opening up more and more strange accusations against my hero"; "to watch the chronology of his [the accused in the case] investigation, to track who says what about him, whether the testimony matches, and so on"; "to review case materials, revealing more and more new details"; "it was sometimes funny due to incorrect wording, crossed out words, followed by the writing of a completely different word, unnecessary words being highlighted; for example, in some places the word diesel was written with a capital letter"; it was interesting to analyse the "interrogations, written by hand... the drawing of a conclusion", "the sequence of events and chance coincidences"; "it was very interesting to read his [the accused's] case, to see what questions were asked during the interrogations, and how they formed and filled in the forms/verdicts/rulings/petitions"; "to find out the life history of the accused, the characteristics that were considered necessary to indicate in the questionnaire"; it was "scary and at the same time interesting to study the materials, and learn more and more about the repressions... like putting together jigsaw puzzles".

All this enabled the teenagers to feel like an investigator, some kind of detective who is investigating "the secrets and events of that time", and reading "an interesting, fantastic book".

The uniqueness, inaccessibility, mystery, dilapidation, illegibility (as a symbol of elusive knowledge, of a mystery, a hidden crime - especially in cases where the documents are handwritten) - all of this makes working with the casefile very attractive for the teenagers, like a kind of quest.

As you progress through this quest, reading the contents of the investigative case materials, yet another emotion - surprise - gains intensity. What turns out to be unexpected for the modern teenager?

The logic of responses is formed in a sequence: from the stating of a fact, through surprise (the acts are absurd, illogical, ridiculous) to the assessment of people and periods (sometimes through rhetorical questioning): "The charge was completely unfounded... there was no direct evidence whatsoever, and they were still sent to a camp for five years"; "I was surprised by the inconsistencies in the case, for example, the extra son, the children's years of birth"; "some of the questioning and testimony was just fake"; "For me the most amazing thing was the form of questioning of the suspect whereby his denial of involvement was simply met with vague counter-arguments; it was clear that the investigator was deliberately trying to 'inundate' Kondratiev"; it was surprising that "a man could be punished for words they hadn't said, and what's more, they 
could be put behind bars for four years"; "I was surprised that a person could be put in jail even in the absence of evidence, and kept in custody"; "People who barely had anything to do with the life of foreign states were immediately put down as spies, without any honest trials being conducted"; "The most surprising thing for me was and remains that investigators can assign a case to an innocent person and put them in prison, just by forcing them to sign some papers"; "Some people immediately confessed to what they had not done"; etc.

An important feature of working with the case is the credibility and plausibility of the "crimes" of the accused, which are sketched out by the investigator through the complaints and denunciations against them, resulting from the interrogations of witnesses. Many of the teenagers began to believe that "this was a terrible person" - right up until they read the prosecutor's appeal and the decision to rehabilitate them: "When I read that he had been rehabilitated, I became very interested in reviewing the case again"; "I did not suspect that the testimony could be falsified. But when I realized that, I was extremely surprised".

At this point, the presumption of trust in the state as one of the basic foundations of a sense of security is questioned and undermined - this is what worries the teenagers most and causes strong emotions: "Reading further and further, I became more and more amazed - why did all this happen?"; "For me, it was surprising that people had no conscience or humanity in those days. They groundlessly imprisoned, killed and tortured innocent people; I was very much surprised that such cruelty and injustice existed in the 30s"; "I was very surprised how people can act towards each other"; this "caused a sense of injustice and insecurity for the well-being of an honest person at that time"; "In these documents I found another confirmation of how cruel and merciless, yet meaningless the mechanisms of repression were at that time... it seemed to me very shocking and sad".

Sadness was the third most intense emotion noted by teenagers on the list. The surprise of acquainting themselves with the contents of the casefile, of encountering unexpected facts (absurd, forged, with gross errors, with real sentences, and the same real rehabilitations "for lack of corpus delicti") invariably led to sadness. Sadness was expressed both as sorrow, and as pity for the victims: "I felt sorry for my hero, his family, his friends"; "I felt sorry for the innocent people who just happened to be in the wrong place at the wrong time. I felt sorry for those people who were broken, whose inner core was pulled out by force"; "I felt very sorry for Victor, who died in prison, where he should not have been"; it was "a shame that the relatives did not find out that the case against their family member was dropped after almost 30 years"; "It was sad 
to read the letters of the brother, who was worried about Reinhold"; "I was sad because of the fate of this man and his life".

Moving forward, sadness could split into a whole palette of stronger emotions, from calm and contemplative sadness to bewilderment, incomprehension ("I was sad that such uneducated people clumsily wrote strange stories"), indignation, and even to some extent anger ("It was... a shame for the fate of this person. He was only 31 years old, and through such a coincidence of circumstances, his life quickly ended. It's just an offensive injustice"; "My soul was torn to pieces when one document or other spoke about the life of the victim. Whether the victim had family, children, or friends. The repressions traumatized many, they took away innocent people").

In its most extreme manifestations, the sadness caused by the realization of the injustice committed against innocent people turned into anger, disgust, and contempt - in relation to "the government that did it", "the investigator and the system", to people who "were almost animals, ready to tear anyone to pieces for their own benefit and to 'protect' the people"; "Any person could say such nonsense that immediately a person could be sent to prison, or worse still, shot"; "They felt superior to other people. They could mock others who they thought were weaker than them. They were arrogant". From the above quotes, it can be seen that the vector of open active condemnation is aimed not only - as is obvious from the investigation casefiles - at the criminals who signed and carried out the sentences (conventionally termed investigators-executioners, who were later also arrested and convicted). It is also aimed at the government and the state system as a whole, within which these crimes became possible, and at a society in which there were people who were able to "talk nonsense".

Because working with an archival investigation casefile combines both a real contact with history (whereby the casefile itself acts as substantiated history/ an artifact) and a symbolic contact (when reading the contents of the case and feeling the fates of specific people that unfold on several tens (hundreds) of yellowed pages), it is possible to quickly and effectively switch on the mechanism of empathy as one of the key mechanisms for the formation of an affiliative postmemory.

Co-attunement occurs at the level of the simultaneous projection of one's own emotions into the past, and the appropriation of the emotions and experiences of the convicts and their relatives, as the teenagers themselves imagine them (often these emotions are hidden between the lines and only sometimes appear in letters, petitions, and other documents), and it is the feeling of fear which becomes the medium between the past and the present (an instrument of chronographic cross-linking). 
It is curious that this is not a fear of the past ("Oddly enough, I felt no fear... I felt sorry for the innocent people who just happened to be "in the wrong place at the wrong time"; "I didn't really feel fear, because it was not happening to me"), but rather a fear of the present: "I wouldn't want to face that in my time. It is a terrible feeling of helplessness, of doom. Betrayal. The horror of everything that is happening - what a person does to a person"; "Fear came about from the thoughts that something like this could easily happen right now and from not understanding how it can be overcome"; "It frightens me that this may happen again".

In this way, the declared duty of memory in relation to the past becomes a manifesto of protection from repetition of this horror in the present. The fairly stable emotions of guilt and shame, directed as it were at the past, when combined with surprise and indignation at the injustice of the era of political repression, obviously appeal to the present day: "It is very unpleasant to realize that your ancestors, your compatriots could do this. To send a woman with two children to five years in the camps, without actually having any exact confirmation of her involvement in the [counter-revolutionary] activities, just because her husband had admitted his guilt (which was also not true)"; "I was sorry that this had happened... I was ashamed of the past because people deliberately put other people behind bars. They deprived them of everything... A person was simply taken away on false charges and that was that"; "I felt guilt and shame for the people and for their attitude to other people just like them"; "I felt shame that an arrested person could be convicted illegally"; "After working with the archive case, I felt depressed, it was unpleasant. I still feel ashamed and disgusted that there is such a shameful page in the history of my country".

The process of "feeling your way" into history through interaction with an authentic space and document, of gaining an affiliative level of postmemory about the era of political repression was, to a certain extent, in tune with the "work of grief" described by Etkind, by which he means "response to the state of Another" as opposed to trauma as "response to one's own state" (Etkind 2016: 27). Etkind emphasizes that the first generation, the victims of repression, know no trauma; it is experienced instead by the survivors - the generation of descendants, children, and only the third generation - the grandchildren of the victims, criminals, and witnesses - do not experience trauma, but grief for their grandparents (Etkind 2016: 13). The author notes that grief, cognition, and revenge are the cultural and psychological processes that combine to overcome post-catastrophic psychological states. A fundamental characteristic of grief is the desire to find out what really happened, a desire which is not present in those who suffered the trauma directly (Etkind 2016: 19). 


\section{CONCLUSION}

Analysis of the impact of an immersive performance on teenagers from the point of view of forming an affiliative postmemory shows that the practices used in the performance worked towards a conditional re-traumatization through the provoked experience of their own experiences and the memory of their own experiences projected onto the past. That is, even if it was in the form of a game, in a specially organized space, nonetheless a kind of reproduction of traumatic experience took place, whereby chronographic cross-linking helped to mix together the past and the present. On the other hand, the beginning of the performance with the story about the "Masks of Sorrow" monument at the memorial, and the end of the performance in the space of the memorial slabs, where the participants were asked to search for their namesakes, became a means of distancing, which could protect the mourner from the risks of a traumatic past. It became a difference marker, a reminder of the separation between the past and the present (Etkind 2016: 37).

It is probable that, by combining the work of repetition and remembering, which results in the humanization of history, the acquisition by the adolescents of individual emotional experiences (of themselves as victims, relatives of victims, executioners) and co-experiences of those unjustly affected by the state system helps them to begin to rethink and to rid themselves of the narrative of redemption (the justification of repression), which hinders any understanding of a catastrophic past.

The same applies to working with the archived investigation casefile: in this instance, the marker for distinguishing between the past and the present was the very place where the familiarization with the document happened - the archive as a repository of documents from the past and about the past, and the cover of the casefile, which serves as a symbolic border between what was then and what is now.

The mechanism of distancing can also be seen in the analysis of the emotional experiences of the adolescents. Probably, the manifestation of a spectrum of negative emotions, provoked by interaction with an authentic space and/or an artifact from the era of political repression, was the result of the actualization of latent fears and anxieties in the lives of the teenagers about their own physical and psychological safety.

As part of the game (playing the victim/executioner - performance, playing the investigator/researcher - working with the archive and investigation casefile), the articulation of acute negative and disturbing experiences became possible due to the security of the game space, which can be entered and exited, 
having experienced and left behind anger, disgust, wrath, shame, and guilt inside it, while taking interest, surprise, and sadness beyond it (the most intense emotional conditions before and after the performance and work with the casefile).

The principle of distancing is also important here because the game is "one of the main phenomena of human existence (along with love, death, domination and labour), which has the ability to reflect human existence in its entirety, and therefore acts as a most important means for the self-objectification of a person in culture (E. Fink)" (Gramatchikova 2004: 5), that is, experiences inside the game and outside the game are equally authentic.

Thus, note can be made of the effectiveness of the selected practices for working with grief and (the beginning) of recognition, understanding, and overcoming the apocalyptic past. Quantitative and qualitative research methods have allowed us to reveal features of the interaction of the recipient of immersive practices with an authentic space (the memorial to victims of political repression) and an authentic artifact (the archival investigation casefile) on a physical, symbolic, and emotional level, to show the emotional connection to the subject, in which information is of particular depth through feelings truly experienced. This study helps to reveal and analyse the internal mechanisms of forming an affiliative postmemory in adolescents about the era of political repression.

\section{NOTES}

1 The project "You can't keep silent: Practices of memory about the era of political repression" was supported by the Presidential Grants Fund in 2019. The main idea and goal of this project are to look for and create new memory practices about the era of political repression from the 1930s to the 1950s with help from adolescents (see the project website at http://12memorial.ru/molchat-rasskazyvat, last accessed on 19 May 2021).

2 We can read the following description about this original performance on the website of the Museum of the History of Yekaterinburg: "The Route of Memory is a documentary audio performance on wheels, dedicated to the private stories of victims of political repression during the Great Terror. This is a unique opportunity not only to visit the memorial, having already felt the theme thanks to the living memories of people, but also to see the imprint of the Great Terror on our city. The audio performance is based on more than 30 interviews with relatives of those executed in the Sverdlovsk region in 1937-1938. These were supplemented by excerpts from historical documents and casefiles of the repressed, recorded by actors from the Open Studio Theatre. The audio performance presents the stories of ordinary citizens and prominent figures of Sverdlovsk, such as I.D. Kabakov - the first secretary of the Sverdlovsk regional committee of the CPSU, V.M. Tarik - the initiator of the creation of the Sverdlovsk 
Palace of Pioneers, etc." See the project website at http://m-i-e.ru/marshrutpamyaty, last accessed on 19 May 2021.

3 This is also a project of the Museum of the History of Yekaterinburg, which was implemented by the director and actors of the Open Studio Theatre in the space of the memorial to the victims of political repression near Yekaterinburg. This article is devoted to analysing the effect of that performance. See the project website at http://m-i-e.ru/delo39496, last accessed on 19 May 2021.

4 The task was formulated as follows: "Please mark in the table the feelings and emotions that you now experience when thinking about the repressions of the $1930 \mathrm{~s}-1950 \mathrm{~s}$, and indicate the degree of their intensity (for 100\%, take the highest degree of intensity of this feeling that you have experienced in your life, for $0 \%$ - the absence of this feeling/ emotion)".

\section{SOURCES}

Questionnaires and interview materials from 2019-2020 in possession of the author.

\section{REFERENCES}

Dorman, Veronika 2010. Ot Solovkov do Butovo: Russkaia Pravoslavnaia Tserkov' i pamiat' o sovetskikh repressiiakh v postsovetskoi Rossii. [From Solovki to Butovo: The Russian Orthodox Church and Memory of Soviet Repression in Post-Soviet Russia.] Laboratorium: Zhurnal sotsial'nykh issledovanii, No. 2, pp. 327-347. Available at http://ecsocman.hse.ru/text/33438722/, last accessed on 16 June 2021.

Etkind, Aleksandr 2016. Krivoe gore: Pamiat' o nepogrebennykh. [Warped Mourning: Stories of the Undead in the Land of Unburied.] Moscow: Novoe literaturnoe obozrenie.

Gramatchikova, Natalia 2004. Igrovye strategii v literature Serebrianogo veka (M. Voloshin, N. Gumilev, M. Kuzmin). [Game Strategies in the Literature of the Silver Age (M. Voloshin, N. Gumilev, M. Kuzmin).] Avtoreferat dissertatsii na soiskanie uchenoi stepeni kandidata filologicheskikh nauk. Ural'skii gosudarstvennyi universitet. Available at https://elar.urfu.ru/bitstream/10995/317/2/urgu0257s. pdf, last accessed on 19 May 2021.

Hirsch, Marianna 2016. Chto takoe postpamiat'? [What is Postmemory?] Transl. by K. Kharlanova. Available at http://urokiistorii.ru/article/53287, last accessed on 19 May 2021.

Ilyin 2016 = Il'in, Vladimir. "Chuvstva" i "emotsii" kak sotsiologicheskie kategorii. ["Feelings" and "Emotions" as Sociological Categories.] Vestnik SPbGU, Sotsiologiia, No. 4, pp. 28-40. https://doi.org/10.21638/11701/spbu12.2016.402. 
Kotlomanov, Aleksandr 2017. Monumental'nost' novoi russkoi skul'ptury. Epizod 2: "Stena skorbi". [The Monumentality of New Russian Sculpture. Episode 2: "The Wall of Grief".] Vestnik SPbGU: Iskusstvovedenie, Vol. 7, No. 4, pp. 436-452. https://doi.org/10.21638/11701/spbu15.2017.405.

Kunitsyna, Valentine 2011. Metodika "Shkala differentsial'nykh emotsii" by K. Izard. Adaptatsiia A.B. Leonovoi. [C. Izard's Methodology "Differential Scale of Emotions”. Adapted by A.B. Leonova.] In: A.A. Bodalev (comp.) Psikhologiia obshcheniia. Entsiklopedicheskii slovar'. Moscow: Kogito-Tsentr. Available at https://www.psyoffice.ru/6-1095-metodika-shkala-diferencialnyh-yemocii.htm, last accessed on 19 May 2021.

Oushakin 2014 = Ushakin, Sergei. Vspominaia na publike: Ob affektivnom menedzhmente istorii. [Remembering in Public: On the Affective Management of History.] Gefter, 14 November. Available at http://gefter.ru/archive/13513, last accessed on 19 May 2021.

Simonova, Olga 2016. Bazovye printsipy sotsiologii emotsii. [Basic Principles of the Sociology of Emotions.] Vestnik SPbGU, Sotsiologiia, No. 4, pp. 12-27. https:// doi.org/10.21638/11701/spbu12.2016.401.

Simonova, Olga 2018. Izuchenie emotsii kak oblast' mezhdistsiplinarnoi integratsii: istoriia i sotsiologiia v poiskakh ob"iasneniia "emotsional'nogo povorota". [The Study of Emotions as an Area of Interdisciplinary Cooperation: The History and Sociology of Emotions in the Search for the Explanation of "Emotional Turn".] Sotsiologicheskoe obozrenie, Vol. 17, No. 3, pp. 356-378. Available at https:// sociologica.hse.ru/2018-17-3/224869803.html, last accessed on 19 May 2021.

Sklez, Varvara 2016. Affektivnoe utochnenie vremeni. Retsenziia na knigu: Schneider R. (2011) Performing Remains. Art and War in Times of Theatrical Reenactment, Routledge. [Affective Time Refinement. Book Review: Schneider R. (2011) Performing Remains. Art and War in Times of Theatrical Reenactment, Routledge.] Sotsiologiia vlasti, No. 2, p. 226.

Strelova, Olga 2012. Istoriia v shkole ostaetsia "polem bitvy za proshloe", potomu chto "voiny pamiati" ne utikhaiut. [History Classroom - Still "a Field of Battle for the Past", as "Memory Wars" Rage On.] Problemy sovremennogo obrazovaniia, No. 6, pp. 83-98. Available at https://cyberleninka.ru/article/n/istoriya-v-shkoleostaetsya-polem-bitvy-za-proshloe-potomu-chto-voyny-pamyati-ne-utihayut/ viewer, last accessed on 19 May 2021.

Zevako, Yulia 2019. Formirovanie "Affiliativnoi postpamiati' ob epokhe politicheskikh repressii (na primere podrostkov - obuchaiushchikhsia 9-11 klassov). [Creation of "Affiliative Postmemory" about the Epoch of Political Repressions (on the Example of Teenagers - Pupils of 9th to 11th forms).] Journal of Frontier Studies, Vol. 4, No. 2, pp. 390-409. https://doi.org/10.24411/2500-0225-2019-10042. 
Yulia V. Zevako (PhD) is Researcher at the Institute of History and Archaeology of the Ural Branch of the Russian Academy of Sciences, Russia. Her research focuses on the phenomena of identity, ethnicity, national politics and nationalism, politics and practices of memory as part of the phenomenon of identity, trauma and memory studies.

milirita@rambler.ru 